\title{
TEMPORAL DIFFERENCES IN BLOOD MEAL DETECTION FROM THE MIDGUTS OF Triatoma infestans
}

\author{
Jesus PINTO(1), Dawn M. ROEllig(2), Robert H. GILMAN(3), Maritza CALDERón(1), Carlos BARTRA(1), Renzo SALAZAR(1), Caryn BERN(2), \\ Jenny ANCCA-JUÁREZ(1), Michael LEVY(4), Cesar NÁQUIRA(1) \& Vitaliano CAMA(2)
}

\begin{abstract}
SUMMARY
We used genus/species specific PCRs to determine the temporal persistence of host DNA in Triatoma infestans experimentally fed on blood from six common vertebrate species: humans, domestic dogs, guinea pigs, chickens, mice, and pigs. Twenty third or fourth instar nymphs per animal group were allowed to feed to engorgement, followed by fasting-maintenance in the insectary. At 7, 14, 21, or 28 days post-feeding, the midgut contents from five triatomines per group were tested with the respective PCR assay. DNA from all vertebrate species was detected in at least four of five study nymphs at seven and 14 days post-feeding. DNA of humans, domestic dogs, guinea pigs, pigs, and chickens were more successfully detected (80-100\%) through day 21, and less successfully (20-100\%) at day 28. Findings demonstrate that species-specific PCRs can consistently identify feeding sources of T. infestans within two weeks, a biologically relevant time interval.
\end{abstract}

KEYWORDS: Chagas disease; Blood meal analysis; Triatoma infestans; Trypanosoma cruzi; PCR.

\section{INTRODUCTION}

Trypanosoma cruzi, etiologic agent of Chagas disease, is transmitted by obligate hematophagous triatomine insects in the family Reduviidae (subfamily Triatominae) via the stercorarial route ${ }^{1}$. In Latin America, an estimated eight million people are infected with $T$. cruzi with approximately 60,000 new cases occurring annually, making it one of the most important vector-borne pathogens endemic to the region ${ }^{14}$.

Triatomine vectors have a wide geographic range spanning from the southernmost tip of South America to northern regions of the United States ${ }^{9}$. While a large number of potential vector species exist, the importance of a vector within a particular area depends greatly on the ecology of the setting. Triatoma infestans, for example, is arguably the most important domiciliary vector of $T$. cruzi. Alternatively, Rhodnius robustus, is considered a predominately sylvatic vector ${ }^{5,18}$. For either of these examples, the vertebrate species in which they obtain a blood meal differs. In a sylvatic environment, wild animals act as main blood meal sources; risk of $T$. cruzi transmission to people is limited due to fewer encounters between infected vectors and humans. In the case of T. infestans, the peridomestic and domestic blood meal sources have included domestic dogs, chickens, goats, pigs, cows, domesticated guinea pigs, and humans $\mathrm{s}^{6,7,15,16,17,21}$. In domestic and peridomestic sites, vectors are more likely to feed on humans.
In previous studies, vertebrate blood meal sources for various Triatoma spp. included humans, domestic dogs, rabbits, sheep, opossums, pigs, multiple rodent and bat species, goats, chickens, guinea pigs, lizards, and other insects $2,3,11,13,16,17,23$. This list includes important $T$. cruzi reservoirs for the peridomestic cycle of Chagas disease, such as domestic dogs, guinea pigs, and humans ${ }^{7,10,16,17}$. Chickens, along with all other avian species, are refractory to infection with $T$. cruzi. It has previously been shown that the presence of chickens in an area significantly decreases the number of infected vectors ${ }^{22}$. In contrast, the risk of human $T$. cruzi infection was four times higher if a domestic dog slept in the person's bedroom ${ }^{4}$. Other common animals such as pigs, chickens, and rodents may serve as blood sources for peridomestic Triatoma spp., as well as reservoirs of $T$. cruzi.

Determining the species of a vector's blood meal source, termed blood meal analysis, is an important tool for determining both the natural history of a vector species, and the ecology and epidemiology of a vector-borne disease such as Chagas disease. Traditionally, serologic techniques, such as immunodiffusion, double gel diffusion, and precipitin tests have been used to identify the animal species of a blood meal source ${ }^{3,11,23,24}$. These assays require anti-sera against specific groups or species of animals However, the anti-sera against many animal species are not readily available and challenging to generate. Thus, these techniques are not always ideal. Molecular techniques, including multiplex, heteroduplex, and traditional polymerase chain reaction (PCR) methods, that amplify 


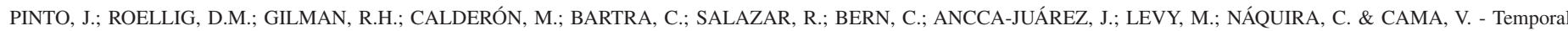
differences in blood meal detection from the midguts of Triatoma infestans. Rev. Inst. Med. Trop. Sao Paulo, 54(2): 83-7, 2012.

high copy-number gene targets, such as mitochondrial genes or repeat elements, are more specific, may have better detection limits, and can be more affordable and efficient ${ }^{2,13,16,17}$.

Of the aforementioned techniques, species-specific PCR has been previously reported to have the highest sensitivity. While the specificity and sensitivity of these assays have been studied previously, the length of time blood meal source DNA remains detectable in the midgut of triatomine vectors has not been explored experimentally for most vertebrate species. In the present study, temporal differences and detection limits utilizing species-specific polymerase chain reactions were assessed for seven vertebrate species that are important in the domiciliary transmission of T. cruzi: Canis familiaris, domestic dog; Cavia porcellus, guinea pig; Gallus gallus, chicken; Mus musculus domesticus, domestic house mouse; Sus scrofa, domestic pig; and Homo sapiens, human. These species were selected because they are known as natural blood meal sources for Triatoma infestans in urban settings with active transmission of Chagas disease.

\section{MATERIALS AND METHODS}

Experimental design. Laboratory-reared third and fourth instar Triatoma infestans nymphs were used for all experimental feedings. Prior to use in the study, the triatomines were fed to repletion with chicken blood every two weeks through each developmental stage and maintained at $28{ }^{\circ} \mathrm{C}$ with a relative humidity of $70-80 \%$. Nymphs were starved for four weeks prior to the commencement of the study.

Triatomines were randomly separated into seven experimental groups of 20 each. For Canis familiaris, Cavia porcellus, and Gallus gallus, individual groups of nymphs were placed in a mesh cage and fed directly on the animals. For Mus musculus domesticus, Sus scrofa, and Homo sapiens, the nymphs were fed artificially through a membrane feeder $(s)$. All animals were maintained in accordance with the guidelines of the animal use protocol approved by the ethics committee of Universidad Peruana Cayetano Heredia. For direct feeding, animals (one dog, two guinea pigs, and one chicken) were restrained while triatomine nymphs were allowed to feed for 30 minutes. Artificial feeding was carried out using blood obtained from animals and collected in tubes with ethylenediaminetetraacetic acid (EDTA) with the exception of blood from Sus scrofa, which was stored in sodium citrate tubes because of triatomine fatalities observed with other anticoagulants during a preliminary study. For this study, the triatomines were allowed to feed for 30 minutes. As the volume of blood taken up by each triatomine can vary, the triatomines were verified as repletion stage 4 to minimize potential differences in the volume of midgut content $(\mathrm{MC})^{12}$.

On days 7, 14, 21, and 28 post-feeding, five T. infestans from each experimental group were collected and stored at $-20^{\circ} \mathrm{C}$ until dissection for molecular analysis. MC were obtained via dissection and stored in TrisEDTA (TE) buffer (10 mM Tris-HCl pH 8.0, $1 \mathrm{mM} \mathrm{EDTA)} \mathrm{at} \mathrm{a} \mathrm{1:10} \mathrm{ratio.}$ A $100 \mu \mathrm{L}$ aliquot of $\mathrm{MC}$ was washed with two volumes of lysis buffer (10 $\mathrm{mM}$ Tris $\mathrm{HCl} \mathrm{pH} \mathrm{7.6,} 5 \mathrm{mM} \mathrm{MgCl} 2,10 \mathrm{mM} \mathrm{NaCl})$, and centrifuged in an Eppendorf 5424 microcentrifuge (Eppendorf AG, Hamburg, Germany) at $15,800 \mathrm{x} \mathrm{g}$ for two $\mathrm{min}$, and the supernatant was removed. The pellet was resuspended in $300 \mu \mathrm{L}$ lysis buffer, SDS (sodium dodecyl sulfate; final concentration of $0.5 \%$ ) and proteinase $\mathrm{K}$ (final concentration of 0.5 $\mathrm{mg} / \mathrm{mL}$; Invitrogen, Carlsbad, CA, USA). The sample was allowed to incubate overnight at $37^{\circ} \mathrm{C}$ and boiled for five min. DNA was extracted with phenol-chloroform-isoamyl alcohol $(25: 24: 1)$ used at a $1: 1$ ratio with the sample and centrifuged $15,800 \mathrm{x} g$ for five minutes. The first clean layer was collected and further extracted using chloroform-isoamyl alcohol (24:1) used at a 1:1 ratio. The extracted DNA was centrifuged for five min at 15,800 x g, and DNA was precipitated with two volumes of absolute ethanol and sodium acetate $(\mathrm{pH} 6)$, to a final concentration of $0.3 \mathrm{M}$ after one hour at $-70{ }^{\circ} \mathrm{C}$. The samples were centrifuged at 13,000 $\mathrm{x} g$ for $15 \mathrm{~min}$, supernatant removed, and the pellet washed with $70 \%$ ethanol. After drying at room temperature, DNA was resuspended in 50 $\mu \mathrm{L}$ TE buffer and stored at $-20^{\circ} \mathrm{C}$ until used in the PCR analysis.

Molecular analysis. Amplification of dog, guinea pig, mouse, pig, and chicken host DNA from the extracts from MC was achieved using previously published primer sets that target short interspersed nuclear elements (SINE) (Table 1, Fig. 1). The PCR-amplified products are specific for each host species, or family, as in the case of pigs ${ }^{19,20}$. The PCR reactions contained $2 \mu \mathrm{L}$ template DNA, 1 X Buffer containing 10 $\mathrm{mM}$ Tris $\mathrm{HCl}$ and $50 \mathrm{mM} \mathrm{KCl}$ (Invitrogen), $1.5 \mathrm{mM} \mathrm{MgCl} 2,0.2 \mathrm{mM}$ of each dNTP (Invitrogen), $0.2 \mu \mathrm{M}$ (dog, mouse, pig, chicken) or $0.4 \mu \mathrm{M}$ (guinea pig) of each primer, and $0.03 \mathrm{U}$ recombinant Taq polymerase (Invitrogen) at a total volume of $25 \mu \mathrm{L}$. Cycling conditions for dog, and mouse PCR were as follows: $95^{\circ} \mathrm{C}$ for one min, 30 cycles of $95^{\circ} \mathrm{C}$ for $30 \mathrm{~s}, 57^{\circ} \mathrm{C}$ for $30 \mathrm{~s}$, and $72{ }^{\circ} \mathrm{C}$ for $30 \mathrm{~s}$. Cycling parameters for guinea pig and chicken PCR were $95^{\circ} \mathrm{C}$ for one min, 30 cycles of $95^{\circ} \mathrm{C}$ for $30 \mathrm{~s}, 63{ }^{\circ} \mathrm{C}$ for $30 \mathrm{~s}$, and $72{ }^{\circ} \mathrm{C}$ for $30 \mathrm{~s}$. To amplify pig DNA, reactions were run at $95{ }^{\circ} \mathrm{C}$ for one min followed by 30 cycles at $95{ }^{\circ} \mathrm{C}$ for $30 \mathrm{~s}$ and $63{ }^{\circ} \mathrm{C}$ for $30 \mathrm{~s}$. Amplification of the human locus cytochrome b (cyt b) was carried out as previously published ${ }^{20}$. Next, a denaturation step at $95{ }^{\circ} \mathrm{C}$ for five minutes followed by 35 cycles $95{ }^{\circ} \mathrm{C}$ for one minute, $58{ }^{\circ} \mathrm{C}$ for one minute and $72{ }^{\circ} \mathrm{C}$ for one minute, with a final extension at $72{ }^{\circ} \mathrm{C}$ for seven minutes (Table 1). A negative control (PCR-grade water) was included in each set of extractions and PCR amplification as contamination controls. DNA extracted directly from the blood of each animal species was used as positive controls and also in serial dilutions to determine detection limits of each PCR. The quantification of DNA was determined by spectrophotometry using a Nanodrop 2000 instrument (Thermo Scientific, Delaware, USA). Products of PCR amplification were electrophoresed on $2 \%$ agarose gels and visualized by UV light transillumination after ethidium bromide staining.

\section{RESULTS}

PCR amplification at seven and 14 days post-feeding (DPF) was highly successful, with rates between 80 and $100 \%$ for each of the sets of five nymphs (Table 2). Importantly, human, domestic dog, guinea pig, pig, and chicken DNA were also detected in at least 4 of 5 triatomines through 21 DPF. Even at 28 DPF, DNA from these animals was detected in at least one triatomine in each group fed on human, guinea pig, pig and chicken blood, and in five of five T. infestans fed on domestic dogs.

The detection limits for each species-specific PCR are described in Table 1 and Fig. 1. Unexpectedly low detection limits (between 1 and 10 ng of DNA) for the mouse-specific PCR were detected for this protocol, and corroborated through PCR amplification of the MC of triatomines from the feeding study. The limits for detecting DNA of chickens were determined at $0.1 \mathrm{ng} / \mathrm{PCR}$ reaction. These findings did not always pair with our findings from the feeding study. For example, at $28 \mathrm{DPF}$ 


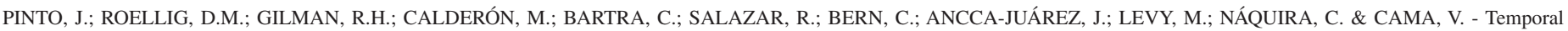
differences in blood meal detection from the midguts of Triatoma infestans. Rev. Inst. Med. Trop. Sao Paulo, 54(2): 83-7, 2012.

Table 1

Detection limits of PCR reactions using varying concentrations of host DNA as template*

\begin{tabular}{|c|c|c|c|c|c|c|c|c|c|}
\hline \multirow{2}{*}{ Species } & \multicolumn{6}{|c|}{ Concentration of DNA (ng) } & \multirow{2}{*}{ Primers $\left(5^{\prime} \rightarrow 3^{\prime}\right)$} & \multirow{2}{*}{ Gene Target } & \multirow{2}{*}{ Reference } \\
\hline & 10 & 1 & 0.1 & 0.01 & 0.001 & 0.0001 & & & \\
\hline Homo sapiens & + & + & + & + & - & - & $\begin{array}{l}\text { (F) GGCTTACTTCTCTTCATTCTCTCCT } \\
\text { (R) GGTTGTCCTCCAATTCATGTTA }\end{array}$ & Cytochrome b & $\begin{array}{l}\text { Kent \& Norris, } \\
2005\end{array}$ \\
\hline Canis familiaris & + & + & + & + & + & - & $\begin{array}{l}\text { (F) AGGGCGCGATCCTGGAGAC } \\
\text { (R) AGACACAGGCAGAGGGAGAA }\end{array}$ & SINEC_CF SINE/dog & $\begin{array}{l}\text { Walker et al., } \\
\quad 2004\end{array}$ \\
\hline Felis catus & + & + & + & - & - & - & $\begin{array}{l}\text { (F) AGTCGGTTAAGCGTCTGACTTT } \\
\text { (R) CTCCAGGCTCTGAGCTGTCA }\end{array}$ & B2_Mv SINE/carnivores & $\begin{array}{l}\text { Walker et al., } \\
2004\end{array}$ \\
\hline Cavia porcellus & + & + & + & + & - & - & $\begin{array}{l}\text { (F) GGGATTTAGCTCAGTGGCATAAG } \\
\text { (R) ATTGGTACCGGGGATTGAACT }\end{array}$ & ID3 SINE/ID & $\begin{array}{l}\text { Walker et al., } \\
2004\end{array}$ \\
\hline Mus musculus & + & - & - & - & - & - & $\begin{array}{l}\text { (F) AGATGGCTCAGTGGGTAAAGG } \\
\text { (R) GTGGAGGTCAGAGGACAAACTT }\end{array}$ & RSINE1 SINE/B4 & $\begin{array}{l}\text { Walker et al., } \\
2004\end{array}$ \\
\hline Sus scrofa & + & + & + & + & + & - & $\begin{array}{l}\text { (F) GACTAGGAACCATGAGGTTGCG } \\
\text { (R) AGCCTACACCACAGCCACAG }\end{array}$ & PRE-1 SINE & $\begin{array}{l}\text { Walker et al., } \\
2003\end{array}$ \\
\hline Gallus gallus & + & + & + & - & - & - & $\begin{array}{l}\text { (F) CTGGGTTGAAAAGGACCACAGT } \\
\text { (R) GTGACGCACTGAACAGGTTG }\end{array}$ & CR1 SINE subfamily C & $\begin{array}{l}\text { Walker et al., } \\
2003\end{array}$ \\
\hline
\end{tabular}

$*(+)=$ positive PCR; $(-)=$ negative PCR; $(\mathrm{F})=$ forward $;(\mathrm{R})=$ reverse.

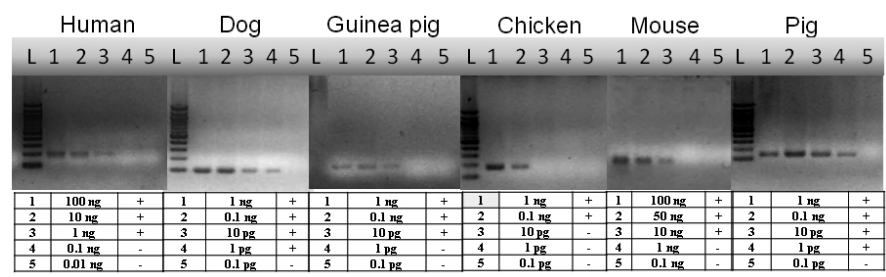

Fig. 1 - Detection limits of the six PCR amplification protocols. L: 100 base pair ladder, products were electrophoresed in $2 \%$ agarose gels.

Table 2

Polymerase chain reaction (PCR) detection of host DNA in engorged Triatoma infestans at intervals of days post-feeding (DPF)*

\begin{tabular}{lcccc}
\hline Blood Meal Host & $7 \mathrm{DPF}$ & $14 \mathrm{DPF}$ & $21 \mathrm{DPF}$ & $28 \mathrm{DPF}$ \\
\hline Homo sapien & $5 / 5$ & $5 / 5$ & $4 / 5$ & $2 / 5$ \\
Canis familiaris & $5 / 5$ & $5 / 5$ & $5 / 5$ & $5 / 5$ \\
Felis catus & $5 / 5$ & $1 / 5$ & $3 / 5$ & $1 / 5$ \\
Cavia porcellus & $5 / 5$ & $4 / 5$ & $4 / 5$ & $2 / 5$ \\
Mus musculus & $4 / 5$ & $4 / 5$ & $0 / 5$ & $0 / 4$ \\
Sus scrofa & $5 / 5$ & $5 / 5$ & $4 / 5$ & $1 / 5$ \\
Gallus gallus & $5 / 5$ & $5 / 5$ & $5 / 5$ & $3 / 5$ \\
\hline
\end{tabular}

$* \mathrm{x} / \mathrm{x}=$ number of PCR-positive bugs/total number of bugs.

chicken DNA was detected in three of five triatomines. The PCR assays used for human, domestic dog, guinea pig, and pig DNA detected lower concentrations of DNA, between $0.001 \mathrm{ng}$ and $0.1 \mathrm{ng}$ of DNA (Fig. 1).

\section{DISCUSSION}

In the present study, blood from six vertebrate hosts was used to determine the temporal detection of host DNA in the MC of $T$. infestans. While previous studies have successfully identified acceptable methodologies and determined the sources of blood meals, experimental methods usually included sampling only up to four DPF ${ }^{8,16}$. Methods using immunological approaches, such as a precipitin test, reported the identification of blood meals up to three months post-feeding ${ }^{24}$. A reliable evaluation of the efficacy of these methodologies for field studies requires that the time between the triatomine blood meal and capture be taken into account.

We assessed the limitations of blood meal analyses while taking into account temporal effects by testing blood-fed T. infestans at seven day intervals up to 28 days post-feeding. Although desirable, we did not extend our study period beyond four weeks due to our own observation of variable mortality among $3^{\text {rd }}$ and $4^{\text {th }}$ stage instars in colony, when subjected to starvation of five weeks or longer. This might have been related to the young age of the triatomines used in our study $\left(3^{\text {rd }}\right.$ and $4^{\text {th }}$ instars), compared to $5^{\text {th }}$ stage nymphs used in other studies ${ }^{24}$.

Our results showed that for humans, domestic dogs, guinea pigs, pigs, and chickens, DNA could be detected with high sensitivity (80$100 \%)$ through day 21 post-feeding with varying levels of success $(20-100 \%)$ at day 28 post-feeding. For human PCR, our time course was significantly longer than that tested in the original methodology in mosquitoes 8 . In the previous study, human DNA could be detected from mosquitoes up to their final time point of 24-30 hours post-feeding compared to $28 \mathrm{DPF}$ in this study. However, the volume of blood taken by a triatomine bug compared to a mosquito is much greater and would account for this variation in human DNA detection. Taken in conjunction with our detection limit results, in which $0.01 \mathrm{ng}$ of DNA was necessary for detection, these findings suggest that this methodology would be a sensitive and efficient method for identifying the blood meal sources in Chagas disease epidemiology studies.

A previous study ${ }^{16}$ utilizing the same guinea pig PCR protocol as in the current study found that $23 \%(8 / 34)$ of $T$. infestans collected 
PINTO, J.; ROELLIG, D.M.; GILMAN, R.H.; CALDERÓN, M.; BARTRA, C.; SALAZAR, R.; BERN, C.; ANCCA-JUÁREZ, J.; LEVY, M.; NÁQUIRA, C. \& CAMA, V. - Temporal differences in blood meal detection from the midguts of Triatoma infestans. Rev. Inst. Med. Trop. Sao Paulo, 54(2): 83-7, 2012.

from guinea pig-inhabited areas were PCR positive after two months of maintenance, unfed, at ambient temperature ${ }^{16}$. In our study, guinea pig DNA was detected in $40 \%$ (2/5) of triatomines maintained until 28 DPF. Together these findings indicate that guinea pig DNA can be detected in T. infestans after extended periods of time post-feeding.

The PCR for mouse DNA was not highly efficient, as it had considerably higher detection limits than all other protocols. Thus, the detection of mouse DNA in MC only through 14 DPF could be a reflection of the lack of robustness of such test. These observations suggest that the PCR based on SINE targets for mouse DNA has limited value for blood meal analyses. This could be supported by a previous field study utilizing the same methodology where mouse DNA was not detected in the MC of triatomines ${ }^{17}$.

Chicken DNA was detectable in all triatomines up 21 DPF and 60\% at $28 \mathrm{DPF}$. Considering that the average digestion time of a blood meal is approximately 14 days in $T$. infestans ${ }^{1,18}$, it may be reasonable to consider that temporal differences in detection of host DNA in MC could also be a reflection of varying times in the digestion or degradation of DNA in the midgut of triatomines.

Importantly, the current study demonstrates that host DNA is detectable during the first 28 days after a blood meal from the midgut of $T$. infestans, a significant vector of $T$. cruzi. Future studies may also consider greater lengths of time between blood uptake and molecular detection, and the utilization of $5^{\text {th }}$ stage nymphs. These findings are of significant value because they allow one better understanding of the feeding habits or preferences of vectors, information that is important to understand the transmission of Chagas disease as well as exposure of susceptible hosts to vectors. Overall, blood meal analyses must be used in conjunction with data from epidemiological surveillance systems to accurately assess the risk of $T$. cruzi in an area.

\section{RESUMEN}

\section{Diferencias temporales en la detección de fuentes de alimentación en el contenido intestinal de Triatoma infestans}

Se utilizó pruebas PCR género o especie específicas para determinar la persistencia temporal de ADN del hospedero en el contenido intestinal de Triatoma infestans que fueron alimentados experimentalmente con sangre de seis vertebrados muy frecuentemente asociados a enfermedad de Chagas: humano, perro, cobayo, pollo, ratón, y cerdo. Se emplearon 20 ninfas de tercer y cuarto estadio por cada especie de hospedero. Fueron alimentados a saciedad y mantenidas en el insectario sin alimentación posterior. Se obtuvo el contenido intestinal de cinco triatominos por cada grupo a los 7, 14, 21 y 28 días post - alimentación, que fueron evaluados con los respectivos PCRs específicos. El ADN de todos los vertebrados fue detectado en al menos 4 de 5 ninfas evaluadas a los 7 y 14 días post - alimentación. El ADN de humano, perro, cobayo, cerdo y pollo fue detectado exitosamente (80-100\%) hasta el día 21 y con menos éxito (20-100\%) en el día 28. Estos resultados demuestran que PCRs específicos para cada especie de hospedero pueden identificar consistentemente la fuente de alimentación de T. infestans dentro de las dos semanas post - alimentación, siendo un intervalo de tiempo biológicamente relevante.

\section{ACKNOWLEDGEMENTS}

We thank the invaluable contributions of the Ministerio de Salud del Perú (MINSA), Dirección General de Salud de las Personas (DGSP), Estrategia Sanitaria Nacional de Prevención y Control de Enfermedades Metaxénicas y Otras Transmitidas por Vectores (ESNPCEMOTVS), Dirección General de Salud Ambiental (DIGESA); Gobierno Regional de Arequipa; Gerencia Regional de Salud de Arequipa (GRSA); Pan American Health Organization (PAHO); and Canadian International Development Agency (CIDA).

\section{FINANCIAL SUPPORT}

This work was supported in part by the National Institute of Allergy and Infectious Diseases projects 5P50 AI074285-03 and 04, 1K01AI079162-03 and 3K01AI079162-02S1, the Centers for Disease Control and Prevention (CDC), and by an appointment (D.M. Roellig) to the Emerging Infectious Diseases (EID) Fellowship Program administered by the Association of Public Health Laboratories (APHL) and funded by CDC.

\section{DISCLAIMER}

The findings and conclusions in this report are those of the author(s) and do not necessarily represent the views of the Centers for Disease Control and Prevention.

\section{REFERENCES}

1. Askew, R. Parasitic insects. New York: American Elsevier; 1971.

2. Bosseno M-F, García LS, Baunaure F, Gastelúm EM, Gutierrez MS, Kasten FL, et al. Identification in triatomine vectors of feeding sources and Trypanosoma cruzi variants by heteroduplex assay and a multiplex miniexon polymerase chain reaction. Am J Trop Med Hyg. 2006;74:303-5.

3. Brenière SF, Pietrokovsky S, Gastélum EM, Bosseno M-F, Soto MM, Ouaissi A, et al. Feeding patterns of Triatoma longipennis Usinger (Hemiptera, Reduviidae) in peridomestic habitats of a rural community in Jalisco State, Mexico. J Med Entomol. 2004;41:1015-20.

4. Crisante G, Rojas A, Teixeira MMG, Añez N. Infected dogs as a risk factor in the transmission of human Trypanosoma cruzi infection in western Venezuela. Acta Trop. 2006;98:247-54.

5. Cuba CAC, Abad-Franch F, Roldan-Rodríguez J, Vargas F, Pollack-Velásquez L, Miles MA. The triatomines of Northern Peru, with emphasis on the ecology and infection by trypanosomes of Rhodnius ecuadoriensis (Triatominae). Mem Inst Oswaldo Cruz. 2002;97:175-83.

6. Giordano R, Cortez JC, Paulk S, Stevens L. Genetic diversity of Triatoma infestans (Hemiptera: Reduviidae) in Chuquisaca, Bolivia based on the mitochondrial cytochrome b gene. Mem Inst Oswaldo Cruz. 2005;100:753-60.

7. Gürtler RE, Cecere MC, Castañera MB, Canale D, Lauricella MA, Chuit R, et al. Probability of infection with Trypanosoma cruzi of the vector Triatoma infestans fed on infected humans and dogs in northwest Argentina. Am J Trop Med Hyg. 1996;55:24-31.

8. Kent RJ, Norris DE. Identification of mammalian blood meals in mosquitoes by a multiplexed polymerase chain reaction targeting cytochrome B. Am J Trop Med Hyg. 2005;73:336-42. 
PINTO, J.; ROELLIG, D.M.; GILMAN, R.H.; CALDERÓN, M.; BARTRA, C.; SALAZAR, R.; BERN, C.; ANCCA-JUÁREZ, J.; LEVY, M.; NÁQUIRA, C. \& CAMA, V. - Temporal differences in blood meal detection from the midguts of Triatoma infestans. Rev. Inst. Med. Trop. Sao Paulo, 54(2): 83-7, 2012.

9. Lent H, Wygodzinsky PW. Revision of the Triatominae (Hemiptera, Reduviidae) and their significance as vectors of Chagas' disease. Bull Am Mus Nat Hist. 1979;163(Art 3):125-520.

10. Levy M, Bowman N, Kawai V, Waller L, Cornejo J, Cordova E, et al. Periurban Trypanosoma cruzi-infected Triatoma infestans, Arequipa, Peru. Emerg Infect Dis. 2006; $12: 1345-52$.

11. López A, Crocco L, Morales G, Catala S. Feeding frequency and nutritional status of peridomestic populations of Triatoma infestans from Argentina. Acta Trop. 1999;73:275-81

12. Montenegro SSC. Determinación de las reservas alimenticias en Triatoma infestans, Klug 1834 (Hemiptera: Reduviidae) en base a caracteres externos adultos. Physys (Bs. As.) Sec. C. 1983;41:159-67.

13. Mota J, Chacon JC, Gutiérrez-Cabrera AE, Sánchez-Cordero V, Wirtz RA, Ordoñez R, et al. Identification of blood meal source and infection with Trypanosoma cruzi of Chagas' disease vectors using a multiplex cytochrome b polymerase chain reaction assay. Vector Borne Zoonotic Dis. 2007;7:617-27.

14. Organización Panamericana de la Salud. Estimación cuantitativa de la enfermedad de Chagas en las Américas. Montevideo. Uruguay. Tech Rep. OPS/HDM/CD/425-06; 2006.

15. Palacios Q, Crisanto D. Enfermedad de Chagas en la provincial de Rodríguez de Mendoza (Dpto. De Amazonas). Rev Perú Med Exp Salud Publ. 1960;13:15-26.

16. Pizarro JC, Lucero D, Stevens L. A method for the identification of guinea pig blood meal in the Chagas' disease vector, Triatoma infestans. Kinetoplastid Biol Dis. 2007;6:1.

17. Pizarro JC, Stevens L. A new method for forensic DNA analysis of the blood meal in Chagas' disease vectors demonstrated using Triatoma infestans from Chuquisaca, Bolivia. PLoS One. 2008;3:e3585.
18. Schofield, C. Triatominae: biology and control. West Sussex: Eurocommunica Publications; 1994.

19. Walker JA, Hughes DA, Anders BA, Shewale J, Sinha SK, Batzer MA. Quantitative intra-short interspersed element PCR for species-specific DNA identification. Anal Biochem. 2003;316:259-69.

20. Walker JA, Hughes DA, Hedges DJ, Anders BA, Laborde ME, Shewale J, al. Quantitative PCR for DNA identification based on genome-specific interspersed repetitive elements. Genomics. 2004;83:518-27.

21. Wisnivesky-Colli C, Ruiz AM, Ledesma O, Gürtler RE, Lauricella M, Salomón DO, et al. Ecologia doméstica de la tripanosomiasis americana: perfil alimentario del Triatoma infestans en una area rural de la provincial de Santiago del Estero, Argentina. Rev Soc Bras Med. Trop. 1987;20:31-9.

22. Vázquez DP, Canale D, Gürtler RE. Effects of non-susceptible hosts on the infection with Trypanosoma cruzi of the vector Triatoma infestans: an experimental model. Mem Inst Oswaldo Cruz. 1999;94:413-9.

23. Zeledón R, Cordero M, Marroquín R, Lorosa ES. Life cycle of Triatoma ryckman (Hemiptera: Reduviidae) in the laboratory, feeding patterns in nature and experimental infection with Trypanosoma cruzi. Mem Inst Oswaldo Cruz. 2010;105:99-102.

24. Zeledón R, Solano G, Zuñiga A, Swartzwelder JC. Biology and ethology of Triatoma dimidiate (Latreille, 1811). III. Habitat and blood sources. J Med Entomol. 1973;10 363-70.

Received: 9 November 2011

Accepted: 24 January 2012 


\section{LIBRARY OF THE SÃO PAULO INSTITUTE OF TROPICAL MEDICINE}

Website: www.imt.usp.br/portal

Address: Biblioteca do Instituto de Medicina Tropical de São Paulo da Universidade de São Paulo Av. Dr. Enéas de Carvalho Aguiar, 470. Prédio 1 - Andar térreo.

05403-000 São Paulo, SP, Brazil.

Telephone: 5511 3061-7003 - Fax: 5511 3062-2174

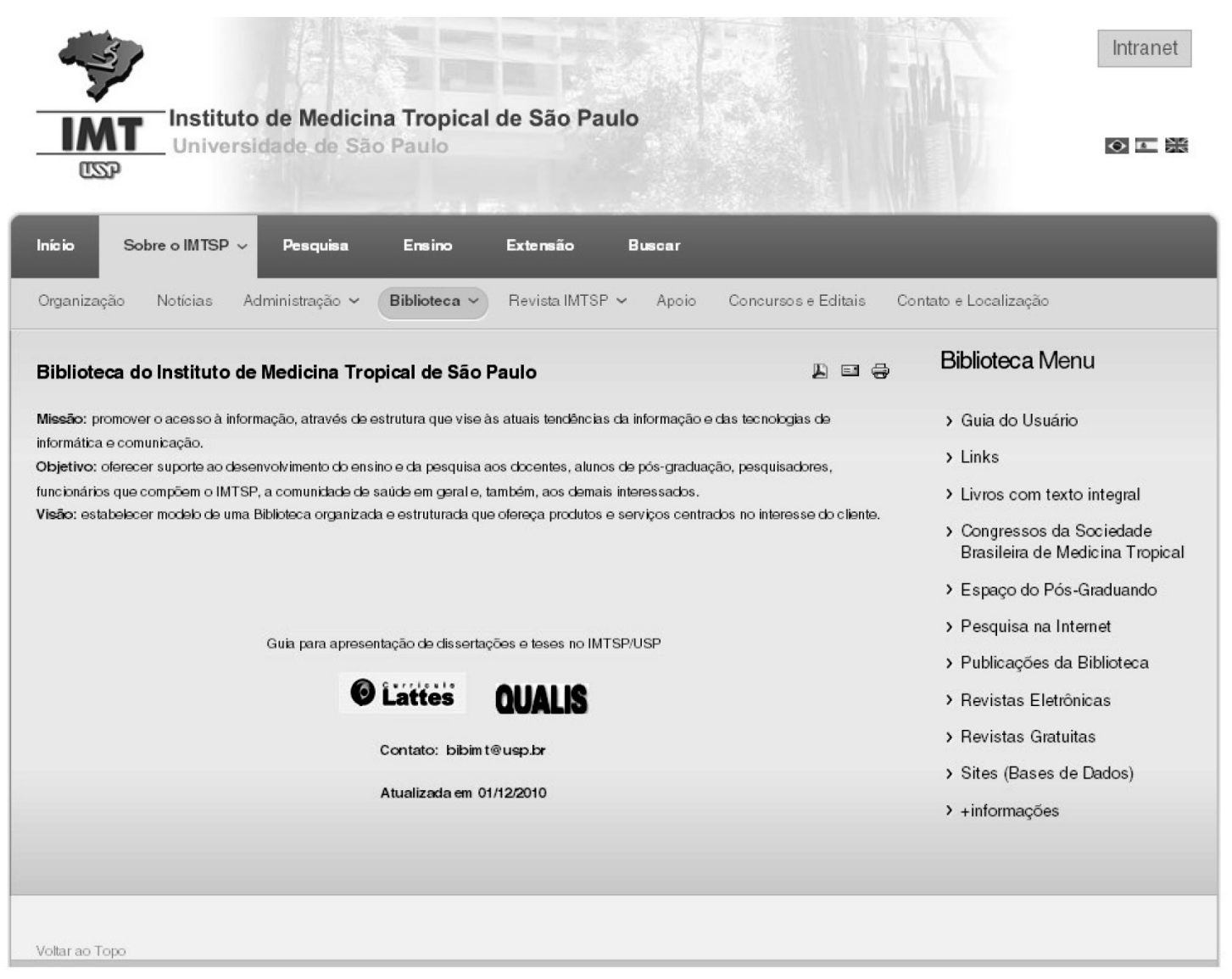

The Library of the São Paulo Institute of Tropical Medicine (IMTSP Library) was created on January 15,1959 in order to serve all those who are interested in tropical diseases. To reach this objective, we select and acquire by donation and / or exchange appropriate material to be used by researchers and we maintain interchange between Institutions thorough the Journal of the São Paulo Institute of Tropical Medicine, since the Library has no funds to build its own patrimony.

The IMTSP Library has a patrimony consisting of books, theses, annals of congresses, journals, and reference works.

The collection fo journals existing in the Library can be verified through the USP - Bibliographic Database - OPAC - DEDALUS http://dedalus.usp.br:4500/ALEPH/eng/USP/USP/DEDALUS/start of the USP network. 